\title{
Principles and practicalities of carrier screening: attitudes of recent parents
}

\author{
Josephine M Green
}

\begin{abstract}
Population carrier screening for cystic fibrosis could soon be a reality, but we know very little about people's attitudes towards genetic disease in general or cystic fibrosis in particular. This paper reports a study which aimed to investigate some of these attitudes and also to explore feelings about CF carrier screening given its practical limitations. The results are discussed in the context of earlier studies which have not raised these practical issues.
\end{abstract}

With the identification of the cystic fibrosis (CF) gene, ${ }^{12}$ population carrier detection is a practical possibility and three pilot studies funded by the Cystic Fibrosis Trust are already under way in the UK. The intention of offering such screening to a general population is to inform people of their carrier risk before they give birth to an affected child. This marks a major departure from previous practice in preventive medicine; we have no precedent for screening of this kind in the UK. Although it might be argued that screening programmes for sickle cell conditions, $\beta$ thalassaemia, and Tay-Sachs disease are comparable because they are also autosomal recessive disorders, their occurrence in the $\mathrm{UK}$ is mostly restricted to ethnic minority groups, and therefore offers no model for mass screening of the population as a whole. Furthermore, even for these conditions, it is apparent that generalisation is not possible from one disease to another or between different cultural contexts (for instance, compare the examples of $\beta$ thalassaemia in Cyprus ${ }^{3}$ or London ${ }^{4}$ with the state of sickle cell screening in the $U^{5}$ ).

We need to know how the population will react to the existence of carrier screening for $\mathrm{CF}$ and, arguably, the best way of finding out is to try it and see. From the pilot programmes that are already operating we will discover what percentage of people accept the offer of carrier screening and, it is to be hoped, we will also learn something about the best way to offer it. For example, whether to use buccal scrapings or blood samples, to test at GP surgeries or in antenatal clinics, and whether to invite people to attend for screening or to test opportunistically.

However, there are important questions to be asked that might not be answered by this 'try it and see' approach. These concern underlying attitudes towards genetic disease in general and CF in particular. For example, should screening be compulsory? Is it believed that people have a social responsibility to avoid the birth of handicapped children? What priority should screening for genetic disease have in NHS budgeting? Are people concerned about possible misuse of genetic information? Such questions could, in principle, be asked of people to whom screening is being offered. However, there is a danger that answers would be biased by a need for cognitive consistency on the part of respondents. ${ }^{6}$ Those accepting testing might feel a need to be positive about screening, while those declining, even if only for pragmatic reasons (such as inconvenient clinic times), might play down the advantages of screening. Arguably, the best way to obtain information about underlying attitudes is to separate these questions from the practicalities of testing, and to ask them of people who are not being offered screening at that time.

Another reason for taking this latter approach lies in the particular uncertainties of CF screening, especially the uncertain prognosis and the fact that, at best, the test will detect only $85 \%$ of carriers. These are features which may be important in people's decision making. Somebody may support the idea of genetic carrier screening for some conditions but not consider the severity of handicap in CF sufficient grounds for avoiding the birth of an affected child. Or, they may want screening because they want the reassurance of knowing that they are not a carrier, in which case they may feel that $85 \%$ sensitivity is not good enough. In order to assess these issues, it is necessary first to raise general questions about genetic screening, free from real life practicalities, and then to introduce these considerations subsequently.

This paper reports a small scale study which examined attitudes towards genetic screening using this approach.

\section{Methods}

Questionnaires were sent to 207 couples who had recently taken part in another questionnaire based study being carried out by our team. This earlier study was of attitudes and experiences concerning prenatal screening ${ }^{7}$ and the women had filled in questionnaires at three points in pregnancy and at six weeks after delivery. Their partners had not been directly involved in the earlier study, although a number had commented that they would have liked to have had questionnaires of their own to fill in. The women had originally been recruited through nine District General Hospitals, all within 60 miles of Cambridge, when they had registered for antenatal care. At the time when questionnaires were sent for the present study, their babies were between 2 and 5 months old. The questionnaire was not sent 
if any of the following applied: (1) neonatal death or congenital abnormality in the most recent pregnancy, (2) major maternal health problems since delivery (including depression), (3) no current partner, (4) reports of a poor relationship with partner, (5) not intending to have more children, (6) scored less than 3 on a scale from 0 to 5 in answer to the question "Have you enjoyed taking part in this research?" (0 meaning not at all, 5 meaning very much). This last question came at the end of the questionnaire that was completed six weeks after delivery, and the purpose of the exclusion was to avoid imposing on people who were unlikely to want to participate.

Because of their participation in the earlier study we had a considerable amount of information about the women, including their reproductive histories, attitudes to prenatal screening, attitudes to abortion, personal knowledge of various handicapping conditions, and background information such as age, occupation, and religion. We also had these last three items for the men.

\section{RESPONSE}

Questionnaires were returned by 104 women and 71 men $(50 \%$ and $34 \%)$. These are lower response rates than we would have expected considering the 'track record' of the women targetted. Although we cannot know the precise reasons for non-response, we are able to compare responders and non-responders in terms of our pre-existing information about them. This shows that responders tended to be older, better educated, and to have higher status jobs than non-responders. There were no significant differences between responders and non-responders in terms of their religion or attitudes to abortion. One couple (responders), out of the 207 targetted, had had a previous child who was handicapped; two (both non-responders) had had previous children who had died.

\section{KNOWLEDGE OF HANDICAPPING DISORDERS}

In the original study women had been asked to say which of a list of handicapping disorders they had heard of. Responses, based on 1607 women in the original study, are given in the table. The table shows that the vast majority of women had at least heard of most of the disorders listed. Ninety-two percent said that they had heard of cystic fibrosis, which is a higher figure than other studies have reported. ${ }^{8}$ Responders were somewhat more likely than non-responders to have heard of the disorders, but, since most of the target group had heard of them, this difference is not significant.

\section{THE QUESTIONNAIRE}

The aim was to produce a questionnaire that could be read and understood by ordinary people with no special knowledge of genetics. In order to do this we found that we also had to produce a short information leaflet which
Percentage of pregnant women who had heard of each of the following disorders at approximately 10 to 12 weeks $(n=1607)$.

\begin{tabular}{lcc}
\hline & No & $\%$ \\
\hline Down's syndrome & 1591 & 99 \\
Spina bifida & 1579 & 98 \\
Cystic fibrosis & 1484 & 92 \\
Muscular dystrophy & 1474 & 92 \\
Cerebral palsy & 1470 & 91 \\
Haemophilia & 1419 & 88 \\
Sickle cell disease & 839 & 52 \\
Anencephaly & 243 & 15 \\
Tay-Sachs disease & 123 & 8 \\
\hline
\end{tabular}

defined some of the main concepts, and participants were asked to read this before attempting to answer the questionnaire. Within the questionnaire itself the intention was to start with basic attitudinal questions about the principles of carrier screening and to move on to more specific scenarios. The questions are given in full in the results section along with the responses given.

\section{Results}

In the first question we postulated a situation designed to elicit attitudes to carrier screening shorn of practical problems such as the test's sensitivity.

Question 1. Suppose that there were a test that could identify carriers for a serious disease that caused children to be born with severe physical and mental handicaps. The test itself would be quite straightforward and $100 \%$ accurate. How do you think that that test should be made available? (Please tick only one box.)

\begin{tabular}{lrr}
\cline { 2 - 3 } & No & $\%$ \\
\cline { 2 - 3 } & & 17 \\
$\begin{array}{l}\text { Everyone should have to have } \\
\text { it }\end{array}$ & 54 & 31 \\
$\begin{array}{l}\text { Everyone should be given it } \\
\text { unless they object }\end{array}$ & & \\
$\begin{array}{l}\text { Everyone should be told about } \\
\text { it and left to decide for }\end{array}$ & & \\
themselves whether or not to & 102 & 58 \\
$\begin{array}{l}\text { have it } \\
\begin{array}{l}\text { It should only be available in } \\
\text { exceptional cases, for example }\end{array}\end{array}$ & & \\
$\begin{array}{l}\text { where there is a family history } \\
\text { It should not be available at all }\end{array}$ & - & - \\
$\begin{array}{l}\text { Don't know } \\
\text { Total }\end{array}$ & 1 & 1 \\
\hline
\end{tabular}

(Percentages do not total 100 owing to rounding.)

It will be seen that most respondents see the decision about carrier screening as one that people should make for themselves. Nevertheless, nearly one-third of the sample thought that the onus should be on people to object if they did not want to be screened, and $15 \%$ of the men (though only $6 \%$ of the women) thought that testing should be compulsory.

The next two questions listed a number of advantages and disadvantages of carrier screening and asked respondents to rate each on a scale of importance from 0 to 3. The advantage of this format is that it allows people 
to express both positive and negative attitudes without forcing them to make judgements about relative importance.

Question 2. There is still a lot of debate about whether or not it is a good idea to have carrier screening programmes. Here are some of the reasons put forward in favour. For each one, please circle a number to indicate how important a reason you think it is, from 0 if you don't think that it is at all important, to 3 if you think that it is very important. Circle '?' if you don't know.

\begin{tabular}{ccccc}
\hline $\begin{array}{c}\text { Not } \\
\text { impor- } \\
\text { tant } \\
0\end{array}$ & \multicolumn{3}{c}{$\begin{array}{c}\text { Very } \\
\text { impor- Don't } \\
\text { tant }\end{array}$} & $\begin{array}{c}\text { know } \\
\text { know }\end{array}$ \\
\hline
\end{tabular}

Parents could be spared

the trauma of having a

handicapped child

$\begin{array}{crrrrr}\text { No } & 1 & 8 & 35 & 128 & 3 \\ \% & 1 & 5 & 20 & 73 & 2\end{array}$

The state could be saved

the costs of handicapped children

$$
\begin{array}{cccccc}
\text { No } & 75 & 49 & 31 & 18 & 2 \\
\% & 43 & 28 & 18 & 10 & 1
\end{array}
$$

People could be reassured that they are not carriers

$\begin{array}{lrrrrr}\text { No } & 2 & 16 & 40 & 116 & 1 \\ \% & 1 & 9 & 23 & 66 & 1\end{array}$

People have a right to know things about themselves

$\begin{array}{lrrrrr}\text { No } & 6 & 17 & 37 & 115 & - \\ \% & 3 & 10 & 21 & 66 & -\end{array}$

Children have a right not to be born with a handicap

$\begin{array}{crrrrr}\text { No } & 15 & 5 & 28 & 104 & 23 \\ \% & 9 & 3 & 16 & 59 & 13\end{array}$

Question 3. Here are some of the reasons that have been put forward against having screening programmes. For each one, please circle a number to indicate how important a reason you think it is, from 0 if you don't think that it is at all important, to 3 if you think that it is very important. Circle '?' if you don't know.

\begin{tabular}{|c|c|c|c|c|}
\hline $\begin{array}{c}\text { Not } \\
\text { impor- } \\
\text { tant }\end{array}$ & & & $\begin{array}{c}\text { Very } \\
\text { impor- } \\
\text { tant }\end{array}$ & $\begin{array}{l}\text { Don't } \\
\text { know }\end{array}$ \\
\hline 0 & 1 & 2 & 3 & $?$ \\
\hline
\end{tabular}

It would worry people

$\begin{array}{rrrrrr}\text { No } & 48 & 69 & 40 & 11 & 7 \\ \% & 27 & 39 & 23 & 6 & 4\end{array}$

You shouldn't interfere with nature

$\begin{array}{crrrrr}\text { No } & 89 & 58 & 11 & 8 & 9 \\ \% & 51 & 33 & 6 & 5 & 5\end{array}$

People who are told that

they are carriers might not understand that their own health was not affected

$\begin{array}{cccccc}\text { No } & 32 & 75 & 43 & 17 & 8 \\ \% & 18 & 43 & 25 & 10 & 5\end{array}$

People who were told that they were not carriers might not understand all the implications of that result

$$
\begin{array}{rrrrrr}
\text { No } & 44 & 70 & 36 & 14 & 11 \\
\% & 25 & 40 & 21 & 8 & 6
\end{array}
$$

The wrong people might

get hold of the

information and use it to

discriminate against

carriers

$\begin{array}{cccccc}\text { No } & 42 & 33 & 42 & 49 & 9 \\ \% & 24 & 19 & 24 & 28 & 5\end{array}$

The programme would use

up NHS resources that

would be better used

elsewhere

$\begin{array}{crrrrr}\text { No } & 87 & 52 & 21 & 3 & 12 \\ \% & 50 & 30 & 12 & 2 & 7\end{array}$

It could lead to an increase

in the number of

abortions (of affected

fetuses)

$\begin{array}{crrrrr}\text { No } & 60 & 41 & 37 & 26 & 11 \\ \% & 34 & 23 & 21 & 15 & 6\end{array}$

It is immediately apparent that this sample is unimpressed by cost based arguments. "The programme would use up NHS resources that would be better used elsewhere" is dismissed by over three-quarters of the sample as being of little importance. Overall the advantages of screening are rated as more important than the disadvantages. Excepting the cost arguments, all the advantages listed attracted a mean rating of 2 or more, while, with one exception, all disadvantages were given a mean rating of less than 1 . The exception was "The wrong people might get hold of the information and use it to discriminate against carriers". Here there was a wide spread of opinion, with men tending to see it as more important than women. Generally, men and women had fairly similar patterns of ratings, although more women thought that it was 'very important' that noncarriers could be reassured $(73 \% v 56 \%)$. Women also saw more of a problem with the possibility that carriers might not understand that their own health was not affected.

The next two questions were designed to investigate beliefs about what carriers should do with that information. Two diseases (' $A$ ' and ' $B$ ') were postulated. For each it was stated that carrier prevalence is approximately 1 in 20; there is only a problem when both parents are carriers; if both parents are carriers then, on average, one out of four of their children will be affected and approximately half will be carriers; prenatal diagnosis would be available and termination would be offered if a pregnancy were found to be affected. The only differences specified between the two diseases were the nature and severity of the handicap. For disease $\mathrm{A}$ it was stated that an affected child would be severely handicapped, both physically and mentally, and would die before the age of 5 . Children affected by disease $B$ would be of normal intelligence, but would have physical problems which could need 
physiotherapy two or three times a day and continuous drug treatment. There would be some periods when they could lead a fairly normal life and they might live for as long as 30 years. Question 4 described only disease A. Once that had been answered, question 5 introduced disease B. We were particularly interested to discover whether parents discriminated between these two situations.

Questions $4+5$. If a person is found to be a carrier which of the following should they do? Remember, both parents have to be carriers, otherwise there is not a problem, and on average three out of four of their children will be healthy. Tick all of the statements that you agree with.

No $\%$

If they are single they should:

$\begin{array}{llrr}\begin{array}{l}\text { Make sure that the } \\ \text { partner they choose } \\ \text { isn't a carrier }\end{array} & \text { A } & 18 & 10 \\ \begin{array}{l}\text { Discuss carrier testing } \\ \text { with any potential }\end{array} & \text { A } & 140 & 11 \\ \quad \text { B } & 150 & 86 \\ \text { partner } & & & \\ \text { Not worry about it } & \text { A } & 24 & 14 \\ & \text { B } & 20 & 11 \\ \text { Decide not to have } & \text { A } & 9 & 5 \\ \text { children } & \text { B } & 9 & 5 \\ \text { Other } & \text { A } & 2 & 1 \\ & \text { B } & 2 & 1\end{array}$

If they have a partner they should:

$\begin{array}{lrrr}\text { Insist that their partner } & \text { A } & 44 & 25 \\ \text { gets tested } & \text { B } & 41 & 23 \\ \text { Encourage their partner } & \text { A } & 126 & 72 \\ \text { to be tested } & \text { B } & 132 & 75 \\ \text { Not worry about it } & \text { A } & 15 & 9 \\ & \text { B } & 12 & 7 \\ \text { Decide not to have } & \text { A } & 9 & 5 \\ \text { children } & \text { B } & 7 & 4 \\ \text { Other } & \text { A } & 4 & 2 \\ & \text { B } & 4 & 2\end{array}$

If both members of a couple are found to be carriers, they should:

$\begin{array}{lrrr}\text { Not have children } & \text { A } & 24 & 14 \\ & \text { B } & 16 & 9 \\ \text { Find other partners } & \text { A } & 3 & 2 \\ & \text { B } & 2 & 1 \\ \text { Have tests during } & \text { A } & 143 & 82 \\ \text { pregnancy to find out } & \text { B } & 149 & 85 \\ \text { if the baby is affected } & & & \\ \text { Have an abortion if the } & \text { A } & 68 & 39 \\ \text { baby is affected } & \text { B } & 45 & 26 \\ \text { Not worry about it } & \text { A } & 4 & 2 \\ & \text { B } & 7 & 4 \\ \text { Other } & \text { A } & 14 & 8 \\ & \text { B } & 12 & 7\end{array}$

(Percentages add to more than 100 since some people gave more than one response for each situation.)
It will be seen that little distinction is being made between the two diseases except that, where both parents are carriers, childlessness or abortion are more likely to be recommended for disease $\mathrm{A}$ than for disease $\mathrm{B}$. There were few differences between men and women, although men were somewhat more inclined to recommend that carriers should remain childless. The greatest difference is seen in the belief that an affected pregnancy should be terminated. While both men and women were more likely to advocate termination for disease A than for disease B, the size of the difference is much greater for women $(44 \% v 25 \%)$ than for men $(31 \% v 27 \%)$

It was then explained that 'Disease B' is cystic fibrosis, that this is the most common serious genetic disease in this country, and that a test for carriers may soon become available. It was also explained that the test would fail to identify 15 carriers out of every 100 tested and what the implications would be of each of the combinations of test results that a couple might get. The explanation concluded as follows.

Question 6. The question is: Is it worth people having such a test under these circumstances? What do YOU think?

$\begin{array}{lrc}\text { Definitely yes } & 105 & 60 \\ \text { Possibly } & 41 & 23 \\ \text { Only if there is cystic fibrosis } & & \\ \quad \text { in the family } & 25 & 14 \\ \text { Definitely not } & - & - \\ \text { Don't know enough to decide } & 4 & 2\end{array}$

Two thirds of men and just over half of the women thought that the test was definitely worth having. Nobody felt that the test was definitely not worth having, and only four people felt that they did not know enough to be able to decide.

Respondents were then asked the following question.

Question 7. If you have answered 'definitely yes' or 'possibly', please tick one box to say how you think it should be available:

$\begin{array}{lcc}\begin{array}{l}\text { it } \\ \text { Everyone should be given it }\end{array} & 8 & 5 \\ \begin{array}{l}\text { unless they object } \\ \text { Everyone should be told about }\end{array} & 59 & 34 \\ \begin{array}{l}\text { it and left to decide for } \\ \text { themselves whether or not to }\end{array} & & \\ \text { have it } & 81 & 46 \\ \begin{array}{l}\text { Don't know } \\ \text { Not applicable }\end{array} & - & - \\ \end{array}$

*Should be 29 , but two answered the question anyway.

This question is essentially the same as the first question. There we were asking for basic attitudes uncluttered by practical considerations. Here we are asking about a particular 
disease and a particular, imperfect, test and our interest was in discovering whether responses would be modified. Comparison of the answers to the two questions shows that $68 \%$ of the total sample gave the same response in both cases; $9 \%$ advocated wider application of screening and $25 \%$ more limited availability. Although the numbers are small, it is perhaps of interest to note that women were consistently less in favour of compulsion than men. Of the eight people advocating compulsory $\mathrm{CF}$ carrier testing, seven were men.

It was explained that there was some debate as to the best time to offer screening, and the pros and cons of the main options were briefly summarised. Respondents were then asked which they favoured.

Question 8. If cystic fibrosis carrier screening were introduced which idea do YOU think would be best?

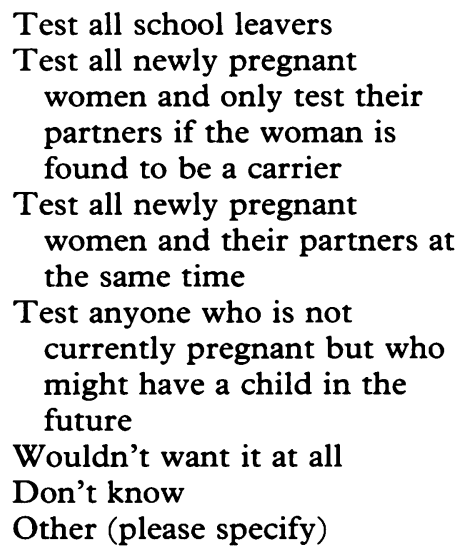

\begin{tabular}{cc}
\hline No & $\%$ \\
\hline 60 & 34
\end{tabular}

$\begin{array}{rr}22 & 13 \\ 1 & 1 \\ 2 & 1 \\ 7 & 4\end{array}$

The single most popular option, chosen by one third of the sample, was testing all school leavers. However, adding together responses to the second and third options, we see that nearly half the sample opted for testing at the start of pregnancy. This seems surprisingly high in a sample who have recently been pregnant and who might, therefore, be expected to appreciate the drawbacks of such timing. However, it may be precisely because of their recent pregnancies that this seemed an obvious choice. Within those favouring testing at the start of pregnancy, two thirds of women thought that men need only be tested if the woman was found to be positive, while men were evenly split between the two options. Testing of non-pregnant prospective parents was not a popular option at all: only $13 \%$ of women and $11 \%$ of men chose it.

The questionnaire concluded by asking the following.

Question 9. Finally, we'd like to know whether or not you think that YOU would be likely to accept the cystic fibrosis test if it were to become available. Please tick one or more of the following boxes.

\begin{tabular}{|c|c|c|}
\hline & No & $\%$ \\
\hline Would definitely not want it & 3 & 2 \\
\hline $\begin{array}{l}\text { Would have it if partner found } \\
\text { to be a carrier }\end{array}$ & 52 & 30 \\
\hline $\begin{array}{l}\text { Would have it if having other } \\
\text { tests done anyway }\end{array}$ & 104 & 59 \\
\hline $\begin{array}{l}\text { Would make a special trip to } \\
\text { have it done }\end{array}$ & 84 & 48 \\
\hline $\begin{array}{l}\text { Would take time off work to } \\
\text { have it done }\end{array}$ & 63 & 36 \\
\hline $\begin{array}{l}\text { Would want it enough to pay } \\
\text { for it }\end{array}$ & 32 & 18 \\
\hline Don't know & 5 & 3 \\
\hline
\end{tabular}

(Percentages add to more than 100 since $46 \%$ of respondents gave more than one response.)

Nearly half the sample said that they would make a special trip to have the test done. This cannot, of course, be taken to be predictive of uptake in practice since this is a self selected sample of people who were interested enough to complete the questionnaire. We might, however, cautiously infer that the $58 \%$ of the target group who were not even interested enough to return the questionnaire would be unlikely to want to make a special trip to have the test done. Of the 52 people who said that they would have the test if their partner were found to be a carrier, five women and nine men gave it as their only response. In one case this included both members of a couple!

There was one final question.

Question 10. Finally, could you please circle a number to let us know how well you feel you understood the issues raised in this questionnaire.

\begin{tabular}{|c|c|c|c|c|c|}
\hline $\begin{array}{l}\text { Didn't } \\
\text { under- } \\
\text { stand } \\
\text { at all } \\
0\end{array}$ & 1 & 2 & 3 & 4 & $\begin{array}{l}\text { Under- } \\
\text { stood } \\
\text { com- } \\
\text { pletely } \\
5\end{array}$ \\
\hline- & - & 5 & 23 & 66 & 80 \\
\hline- & - & 3 & 13 & 38 & 46 \\
\hline
\end{tabular}

(One woman and one man each failed to answer this question.)

\section{Discussion}

Despite the small scale of this survey, a number of interesting points emerge. Subjects made relatively little distinction between different diseases, although such distinctions as were made were in the expected direction. One can compare this with findings from a survey of American students carried out in the $1970 \mathrm{~s},{ }^{9}$ where $54 \%$ advocated termination of TaySachs pregnancies but only $24 \%$ gave this response for haemophilia. In that study, however, the options offered to respondents, for example sterilisation, artificial insemination, were somewhat different from those of the present study. Furthermore, the American sample was better educated and better informed about genetics and genetic disease than our sample. 
The majority of respondents in this study were positive about the basic aims that genetic carrier screening is intended to achieve, although a number clearly did appreciate some of the problems, particularly the possibility that information might be misused. Arguments in favour of screening were consistently rated as important, and arguments against as relatively unimportant. The striking exception to this trend was with respect to economic arguments: both those for and against were rejected by the majority of the sample, even though the form of the question gave them the freedom to rate these alongside other arguments. Cost was not seen as important even when it could be rated without downgrading other choices. This is consistent with other findings on attitudes to medical care.

The sample also showed their general support for genetic carrier screening in their responses to a hypothetical test that would be "quite straightforward and $100 \%$ accurate". Nobody supported the view that such a test "should not be available at all". Once the complex realities of CF carrier screening were introduced, only $60 \%$ were prepared to say that it was definitely worth offering in its present form although another $23 \%$ thought "possibly". The contrast between these two situations probably accounts for the discrepancy between the current findings and those of earlier studies, ${ }^{81011}$ all of which predate recognition of the practical limitations of CF carrier screening and none of which suggested that screening would be other than "quite straightforward and $100 \%$ accurate". A survey in the Netherlands, ${ }^{10}$ for example, found that $80 \%$ of new mothers thought that CF carrier screening should be offered, and the figure was even higher for medical students $(96 \%)$ and for self selected readers of a local newspaper $(90 \%)$. In the recently published study of Edinburgh schoolchildren, ${ }^{11} 86 \%$ thought that routine carrier screening should be offered. This may also account for the numbers saying that they would want to be screened. Williamson $e t$ al ${ }^{8}$ found that $84 \%$ of their sample said that they would want to know if they were a carrier, while in the Dutch study the percentage saying that they themselves would make use of screening varied from $54 \%$ of medical students through $63 \%$ of new mothers to $77 \%$ of newspaper readers. The slightly different emphasis of the phrasing between these two studies probably accounts for the differences between them. However, none of these studies is likely to predict what would happen in practice, as they neither suggest that taking the test has costs of any kind, nor do they indicate the uncertainties of the result. In the present study only $2 \%$ said that they definitely would not want the test but less than half said that they would be prepared to make a special trip to have it.

It is also interesting to compare the present findings with those of earlier surveys in terms of where and when screening might be carried out. In two of the studies cited the participants were not questioned about this, although the authors make recommendations in favour of non-pregnant prospective parents in one case $\mathrm{e}^{10}$ and adolescents in another. ${ }^{11}$ Williamson $e t ~ a l^{8}$ did ask the question of those who favoured screening, giving the options of 'GP surgery', 'referral to hospital', and 'walk in clinic'. Fifty percent favoured the GP, $33 \%$ the hospital, and $17 \%$ the clinic. Testing in pregnancy was not raised as an option. In the present study pregnancy was, in fact, the most common choice. Screening of non-pregnant prospective parents was chosen by only $13 \%$ of the sample and testing of school leavers by $34 \%$. One argument against testing during pregnancy is, of course, that it deprives people of some options, for example, remaining childless or finding other partners. However, these options were not found to have much support in this sample in the hypothetical cases offered; prenatal diagnosis was easily the most popular choice. We need to ask the extent to which people would be likely to choose these other options, and to ensure that if a carrier does choose, for example, to remain childless, that this choice is not made through ignorance of other options. If this were to happen (as is rumoured to be the case in some sickle cell screening programmes) then preconceptual testing would have limited choices, not expanded them.

Testing in early pregnancy has the major drawback of time pressures if fetal testing is indicated and also that it is likely to cause anxiety, ${ }^{12}$ particularly to women found to be carriers. The concept of 'couple screening', ${ }^{13}$ where only carrier couples would be identified, might be one way of ameliorating the disadvantages of testing at this time. Clearly many more people, at least on the basis of the present sample, would be prepared to be screened at this time and, in terms of cost effectiveness, targetting women who are already pregnant and actively involved in health care is more efficient than expending resources on people who may never reproduce in any case.

To what extent can the sample reported here be considered as representative? Firstly we need to ask why the response rate was so low. The sample had been chosen with the expectation of a much higher response rate than that which was actually achieved. Postal studies of pregnant women carried out by our team typically achieve around $70 \%$ response initially and nearer $90 \%$ on follow up. Furthermore, the women targetted had all shown their willingness to complete questionnaires during the course of their recent pregnancies and only those who said that they had enjoyed taking part were included. The target sample was also limited to those who were likely to have further children, the assumption being that the issues would have greater relevance to this group. So why did not more respond? It may be that they were all too busy with their new babies, or that they felt that they had already done enough for us. All had recently had a healthy child which may have led them to think that they were not themselves at risk, and that the subject was not, therefore, relevant to them. It may also be that the issues were difficult to understand, the questionnaire too long, or simply that the topic 
did not engage their attention. These latter explanations seem very likely, particularly when we see that most respondents claim to have had a reasonable understanding of the issues raised. Presumably those who did not understand did not respond. This is a problem inherent in any attempt to offer mass screening: the issues are not simple to understand, neither are conditional probabilities, and the long term implications may not be apparent at all.

The hazards of offering CF carrier screening at present have been clearly described by Wilfond and Fost. ${ }^{14}$ Nevertheless, it is evident that many professionals in the field do not accept all the arguments, especially those relating to the social implications. If professionals have not fully grasped the issues, how then can ordinary lay people be expected to? The results reported in this paper can only be taken as the responses of a minority group who were prepared to grapple with the issues, successfully or otherwise, and not as being representative of all new parents. The problems of ensuring that all potential subjects of carrier screening are making genuinely informed decisions should not be underestimated.

The questionnaire used in this study underwent a number of metamorphoses in the attempt to convey the issues raised by genetic screening to a non-specialist audience. This process was greatly aided by the critical comments of Martin Bobrow, Martin Richards, Helen Statham, and Claire Snowdon, to all of whom I am most grateful.

1 Riordan JR, Rommens JM, Kerem BS, et al. Identification of the cystic fibrosis gene: cloning and characterisation of of the cystic fibrosis gene: cloning and characterisatio

2 Kerem BS, Rommens JM, Buchanan JA, et al. IdentificaKerem BS, Rommens JM, Buchanan JA, et al. Identifica-
tion of the cystic fibrosis gene: genetic analysis. Science tion of the cystic fi
$1989 ; 245: 1073-80$.

3 Angastiniotis $M$. Cyprus: thalassaemia programme. Lancet 1990;336:1119-20.

4 Modell B, Petrou M, Ward RH, et al. Effect of fetal diagnostic testing on birth rate of thalassaemia major in Britain. Lancet 1984;ii:1383-6.

5 Prashar U, Anionhwu E, Brozovic M. Sickle cell anaemia who cares? London: Runnymede Trust, 1985.

6 Festinger L. A theory of cognitive dissonance. Evanston, Illinois: Row Peterson, 1957.

7 Green JM. 'Is the baby alright?' and other worries. Paper presented to the 10th Annual Conference of the Society for Reproductive and Infant Psychology, Girton College, Cambridge, 11 September 1990.

8 Williamson R, Allison MED, Bentley TJ, et al. Community attitudes to CF carrier testing in England: a pilot study. Prenat Diagn 1989;9:727-34.

9 Margolin CR. Attitudes towards control and elimination of genetic defects. Soc Biol 1978;25:33-7.

10 Ten Kate LP, Tijmstra TJ. Carrier screening for cystic fibrosis. Lancet 1989;ii:973-4.

11 Cobb E, Holloway S, Elton R, Raeburn JA. What do young people think about screening for cystic fibrosis? $\mathcal{f} \mathrm{Med}$ Genet 1991;28:322-4.

12 Green JM. Calming or harming? A critical review of psychological effects of fetal diagnosis on pregnant women. Galton Institute Occasional Papers, Second Series, No 2, 1990.

13 Wald N. Parental antenatal screening for cystic fibrosis. Pape presented to a Workshop on Cystic Fibrosis Carrier Screening, Medical Research Council Headquarters, London, 17 December 1990.

14 Wilfond BS, Fost N. The cystic fibrosis gene: medical and social implications for heterozygote detection. $\mathcal{f} A M A$ 1990;263:2777-83. 